\title{
Influence of the Heat Input on the Dendritic Solidification Structure and the Mechanical Properties of 2.25Cr-1Mo-0.25V Submerged-Arc Weld Metal
}

\author{
Hannah Schönmaier (D), Ronny Krein, Martin Schmitz-Niederau, and Ronald Schnitzer
}

Submitted: 16 December 2020 / Revised: 16 March 2021 / Accepted: 25 April 2021 / Published online: 14 June 2021

\begin{abstract}
The alloy $2.25 \mathrm{Cr}-1 \mathrm{Mo}-0.25 \mathrm{~V}$ is commonly used for heavy wall pressure vessels in the petrochemical industry, such as hydrogen reactors. As these reactors are operated at elevated temperatures and high pressures, the $2.25 \mathrm{Cr}-1 \mathrm{Mo}-0.25 \mathrm{~V}$ welding consumables require a beneficial combination of strength and toughness as well as enhanced creep properties. The mechanical properties are known to be influenced by several welding parameters. This study deals with the influence of the heat input during submerged-arc welding (SAW) on the solidification structure and mechanical properties of $2.25 \mathrm{Cr}-1 \mathrm{Mo}-0.25 \mathrm{~V}$ multilayer metal. The heat input was found to increase the primary and secondary dendrite spacing as well as the bainitic and prior austenite grain size of the weld metal. Furthermore, it was determined that a higher heat input during SAW causes an increase in the stress rupture time and a decrease in Charpy impact energy. This is assumed to be linked to a lower number of weld layers, and therefore, a decreased amount of fine grained reheated zone if the multilayer weld metal is fabricated with higher heat input. In contrast to the stress rupture time and the toughness, the weld metal's strength, ductility and macro-hardness remain nearly unaffected by changes of the heat input.
\end{abstract}

Keywords $2.25 \mathrm{Cr}-1 \mathrm{Mo}-0.25 \mathrm{~V}$ weld metal, electron backscatter diffraction, heat input, solidification structure, stress rupture test, submerged-arc welding

\section{Introduction}

The alloy $2.25 \mathrm{Cr}-1 \mathrm{Mo}-0.25 \mathrm{~V}$ was developed in the early $90 \mathrm{~s}$ by combining the properties of $2.25 \mathrm{Cr}$-1Mo-type with the ones of $1 \mathrm{CrMoV}$-type steels. It is commonly used for reactors in power stations or in petroleum and chemical plants (Ref 1-3). Typical applications are, e.g., hydrocracking and desulfurization reactors, which are exposed to elevated temperatures of 400 to $450{ }^{\circ} \mathrm{C}$ and high pressures (Ref 4). As these reactors might be operated under creep conditions, the applied $2.25 \mathrm{Cr}$ $1 \mathrm{Mo}-0.25 \mathrm{~V}$ welding consumables require a beneficial combination of strength and toughness as well as enhanced creep rupture strength (Ref 3-6). For the application in thick walled reactors, the $2.25 \mathrm{Cr}-1 \mathrm{Mo}-0.25 \mathrm{~V}$ steel is commonly joined with submerged-arc welding (SAW) (Ref 5).

$S A W$ is an established manufacturing process with a continuous wire feed and a welding flux which shields the weld pool from the surrounding atmosphere and has numerous functions such as deoxidation, supply of alloying elements and slag formation. There are many factors which directly influence

Hannah Schönmaier and Ronald Schnitzer, Department of Materials Science, Montanuniversiät Leoben, Franz-Josef-Straße 18, 8700 Leoben, Austria; and Ronny Krein and Martin Schmitz-Niederau, voestalpine Böhler Welding Germany GmbH, Hafenstraße 21, 59067 Hamm, Germany. Contact e-mail: hannah.schoenmaier@unileoben.ac.at. the process of SAW and in further consequence possess an impact on the microstructure and mechanical properties of the resulting welded component. The most important ones are the filler metal (i.e., the combination of flux and wire), the applied welding current and voltage, the deposition rate as well as the interpass and preheat temperature (Ref 7-11).

For the process of SAW, where the thermal efficiency factor is close to 1 , the product of welding current and voltage multiplied by 60 and divided by the welding speed equals approximately the heat input $(\operatorname{Ref} 9,12,13)$. A high heat input during SAW causes larger sized weld beads and thus slower cooling rates, leading to differences in the weld metal's bead sequence and microstructure, compared to welding with lower heat input (Ref 12, 14). Especially for welding large components with large wall thickness and a high number of weld seams, welding with higher heat input might offer the possibility to increase the productivity as it enables welding of larger volumes with fewer weld beads. In addition, a higher heat input (increased energy density) during welding enhances the efficiency of melting and therefore increases the amount of molten zone (weld bead) (Ref 15). This, in further consequence, leads to a longer period of time until the temperature falls below the interpass temperature for SAW of $2.25 \mathrm{Cr}-1 \mathrm{Mo}-$ $0.25 \mathrm{~V}$ alloy which might be an alternative to extensive heating to maintain the required temperature.

Furthermore, an increased heat input during welding is known to strongly influence the solidification structure and grain size of the resulting weld metal. Multiple authors (Ref 1619) found that a higher heat input during welding increases the dendrite length as well as the interdendritic spacing in the welded zone and furthermore leads to coarsening of the grain structure and an increased size and volume of the present phases.

Beside the influence of the heat input on the solidification and grain structure of the resulting weld metal, researchers (Ref 
$16,18,20-22)$ also investigated the correlation between the heat input of different welding procedures and the resulting mechanical properties and hardness of the weld metal. Prasad and Dwivedi (Ref 18), e.g., found that for SAW of low alloyed CrMo steel an increase in heat input from 3 to $7 \mathrm{~kJ} \mathrm{~mm}^{-1}$ increases the weld metal's ductility and decreases its ultimate tensile strength (UTS) and $0.2 \%$ yield strength (YS). Kim et al. (Ref 20) and Prasad and Dwivedi (Ref 19) also found that the impact energy increases with higher heat input while investigating different single-pass and multilayer SAW weld metals. In contrast, Viano et al. (Ref 21) and Juan et al. (Ref 22) experienced an opposite behavior. They found that a higher heat input during both double tandem SAW of high strength low alloy steel and mixed gas shielded arc welding of superhigh strength steel causes a strong decrease in the weld metal's impact toughness. In addition, multiple investigations (Ref 16, 18, 21-24) have shown that a higher heat input during arc welding causes a decrease in the micro- and macro-hardness of the weld metal and the adjacent heat-affected zone (HAZ).

To summarize, literature findings on the influence of the heat input on the mechanical properties of the weld metal are quite contradictory. Depending on the welding procedure, the chemical composition and geometry of the weld metal and the applied post-weld heat treatment, the heat input influences the weld metal in numerous ways. Furthermore, it has to be taken into account that the heat input can be changed by varying either only the welding voltage, the welding current or the travel speed or by varying two or even three of these parameters simultaneously. By changing more than one parameter at once, multiple influencing factors might affect the results, making a distinct correlation between heat input and mechanical properties difficult. This is especially the case if in one and the same study weldments are compared even though the heat input was once varied via changing the product of welding current and voltage and, e.g., once via adapting the welding speed. Therefore, within this study the heat input was varied by changing only the travel speed, while the other parameters such as welding voltage, welding current and wire feed speed were kept constant.

While the influence of the heat input on the solidification structure and the mechanical properties has been studied for a variety of weld metals and welding procedures, the influence of the heat input on the weld metals behavior under creep conditions was not comprehensively thematised, to the authors best knowledge. Nevertheless, in particular for creep-resistant alloys such as $2.25 \mathrm{Cr}-1 \mathrm{Mo}-0.25 \mathrm{~V}$, every welding parameter which probably affects the creep strength should be optimized in order to ensure a long and safe application at high temperatures and pressures. Hence, this study intends to investigate the influence of heat input during SAW on the solidification behavior and the mechanical properties of $2.25 \mathrm{Cr}-$ $1 \mathrm{Mo}-0.25 \mathrm{~V}$ weld metal with additional focus on the impact on the weld metals stress rupture behavior.

\section{Experimental}

\subsection{Investigated Material}

The investigated $2.25 \mathrm{Cr}-1 \mathrm{Mo}-0.25 \mathrm{~V}$ multilayer all-weld metal specimens were produced with single-wire SAW using two $24 \mathrm{~mm}$ thick $2.25 \mathrm{Cr}-1 \mathrm{Mo}-0.25 \mathrm{~V}$ steel plates and a 2.25 $1 \mathrm{Mo}$ backing strip. A root gap of $22 \mathrm{~mm}$ and a bevel angle of $0^{\circ}$ were chosen. Table 1 shows the welding parameters in detail.

The heat input $\mathrm{H}$ for submerged-arc welding where the thermal efficiency factor equals approximately 1 is defined as the product of welding current $I$ and voltage $U$ divided by the welding speed $\mathrm{v}$ according to Eq 1 (Ref 12).

$H=\frac{U * I}{v}\left[\mathrm{~J} \mathrm{~cm}^{-1}\right]$

Within this study, the heat input was varied only by changing the welding speed. Table 2 gives an overview of the details of the investigated weld metals, labeled with A to D.

Table 1 Summary of single-wire SAW parameters

\begin{tabular}{lccc}
\hline Polarity & Current & Voltage & Interpass temperature \\
\hline AC & $550 \mathrm{~A}$ & $30 \mathrm{~V}$ & $230{ }^{\circ} \mathrm{C}$ \\
\hline Preheat temperature & \multicolumn{2}{c}{ Welding sequence } & Welding position \\
\hline $200^{\circ} \mathrm{C}$ & $\begin{array}{l}\text { Left } \leftrightarrow \text { right } \\
\text { alternating }\end{array}$ & PA \\
\hline
\end{tabular}

Table 2 Overview of the investigated all-weld metals labeled with A to D produced with different heat inputs

\begin{tabular}{|c|c|c|c|c|c|}
\hline Weld & Welding speed, $\mathrm{cm} \min ^{-1}$ & Heat input, $\mathrm{kJ} \mathbf{c m}^{-1}$ & Weld reinforcement, $\mathbf{m m}$ & Amount of layers & $t_{8 / 5}$-time (calculated), $\mathrm{s}$ \\
\hline A & 50 & 20 & 4.65 & 9 & 18 \\
\hline $\mathrm{B}$ & 41 & 24 & 4.89 & 8 & 25 \\
\hline $\mathrm{C}$ & 35 & 28 & 3.54 & 6 & 35 \\
\hline $\mathrm{D}$ & 31 & 32 & 4.81 & 6 & 45 \\
\hline
\end{tabular}


The table shows that weld metal $\mathrm{D}$ with the highest heat input of $32 \mathrm{~kJ} \mathrm{~cm}^{-1}$ has the same amount of layers as weld metal C with a lower heat input, but exhibits a higher weld reinforcement. In addition, the calculated $t_{8 / 5}$-times are shown for the last weld beads, which are defined as the time for cooling the weld metal from 800 to $500{ }^{\circ} \mathrm{C}$. The calculation was conducted by means of the voestalpine welding calculator according to DIN EN 1011-2 (Ref 25, 26).

Figure 1 shows the calculated $t_{8 / 5}$-times depending on the applied welding speed and the heat input. A lower welding speed during SAW causes a bigger melt pool and therefore increases the $t_{8 / 5}$-time and thus prolongs the time for solidification.

The mean values of the chemical compositions of the four weld metals A, B, C and D are given in Table 3. Furthermore, the values of the Bruscato $(X)$ and the Watanabe factor $(J)$, which were calculated according to Eq 2 and 3, are provided (Ref 27).

$X=\frac{(10 \mathrm{P}+5 \mathrm{Sb}+4 \mathrm{Sn}+\mathrm{As})}{100}(\mathrm{ppm})$

$J=(\mathrm{Si}+\mathrm{Mn}) *(\mathrm{P}+\mathrm{Sn}) * 10^{4}(\mathrm{wt} . \%)$

The value of the $J$ Factor is below the limit of $J \leq 100$ and the value of the $X$ Factor is below the limit of $X \leq 15$, which according to API Recommended Practice 934-A (Ref 27) minimizes a low alloyed $\mathrm{CrMo}(\mathrm{V})$ steels and weld metals risk to temper embrittlement.

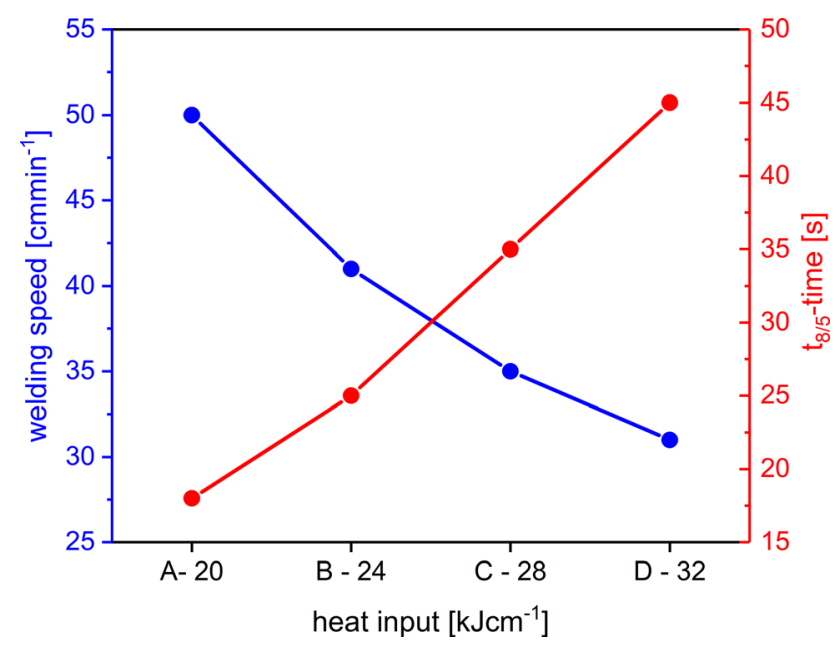

Fig. 1 Correlation between applied welding speed, heat input and calculated $\mathrm{t}_{8 / 5}$-time during multilayer $\mathrm{SAW}$ of $2.25 \mathrm{Cr}-1 \mathrm{Mo}-0.25 \mathrm{~V}$ steel
Beside the elements shown in Table 3, the weld metals also contain $\mathrm{P}$ and $\mathrm{S}$ in small amounts ( $\leq 100 \mathrm{ppm})$.

\subsection{Light Optical Microscopy}

To contrast the primary and secondary dendrites of the welds in their as-welded state, the all-weld metal specimens were cut normal to the welding direction (cross section) and ground with $\mathrm{SiC}$ paper. After grinding, the samples were polished with $3 \mu \mathrm{m}$ and $1 \mu \mathrm{m}$ diamond suspension and treated with Béchet-Beaujard etchant $[100 \mathrm{ml}$ cold saturated filtered picric acid, $1 \mathrm{~g}$ natriumdodecyl-benzolsulfonat, 1-2 drops hydrochloric acid (Ref 28-31)]. Further information about the application of Béchet-Beaujard etchant on creep-resistant $2.25 \mathrm{Cr}-1 \mathrm{Mo}-0.25 \mathrm{~V}$ weld metal can be found elsewhere (Ref 32).

To analyze the mean primary $\left(\lambda_{\text {prim }}\right)$ and mean secondary dendrite spacings $\left(\lambda_{\mathrm{sec}}\right)$, light optical microscopy (LOM) analysis was conducted on the etched cross sections. For robust statistics, 5 LOM pictures within the last weld bead were taken for each all-weld metal specimen, in order to analyze a sufficient number of primary and secondary dendrites. For this purpose, a LOM Zeiss Axio Imager M1m was used. Figure 2 shows a schematic drawing of the weld metals cross section. The LOM pictures were taken in the last weld bead of the multilayer weld metals in order to exclude influences resulting from reheating from further weld beads and to ensure a sharply contrasted dendritic solidification structure, see green colored and blue outlined area in Fig. 2. The green arrows exemplarily show the direction of the dendritic solidification. The dendrites are oriented approximately parallel to the surface of the allweld metal cross section.

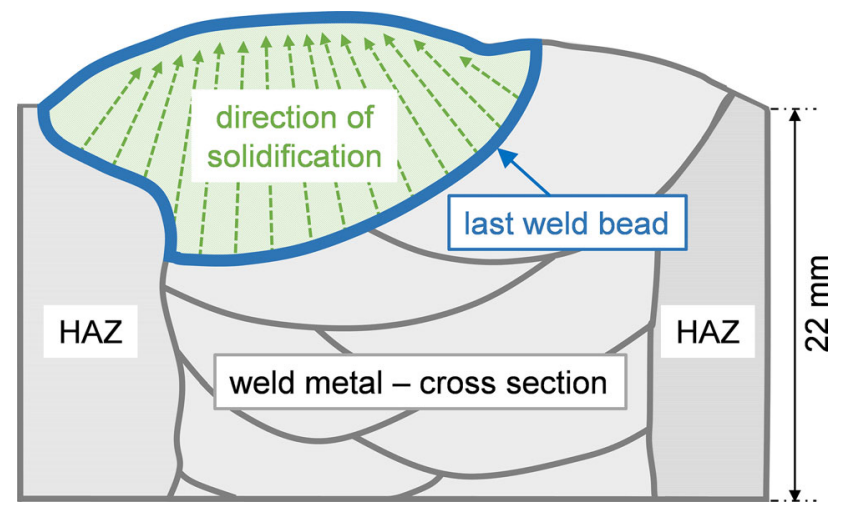

Fig. 2 Schematic image of the all-weld metal cross section and the adjacent heat-affected zone (HAZ) to the base metal. The last weld bead where the LOM pictures for the determination of the dendrite spacings were taken is outlined in blue.

Table 3 Average chemical composition of the investigated all-weld metals in wt.\%

\begin{tabular}{|c|c|c|c|c|c|c|}
\hline $\mathrm{Fe}$ & $\mathrm{Cr}$ & Mn & Mo & $\mathbf{V}$ & C & $\mathrm{Cu}$ \\
\hline bal. & 2.30 & 1.2 & 1 & 0.3 & 0.085 & 0.04 \\
\hline Si & Nb & $\mathbf{N i}$ & $\mathbf{A l}+\mathbf{T i}$ & $\mathbf{O}+\mathbf{N}$ & $X$ Factor & $J$ Factor \\
\hline 0.09 & 0.02 & 0.07 & 0.01 & 0.04 & 6.48 & 84.5 \\
\hline
\end{tabular}




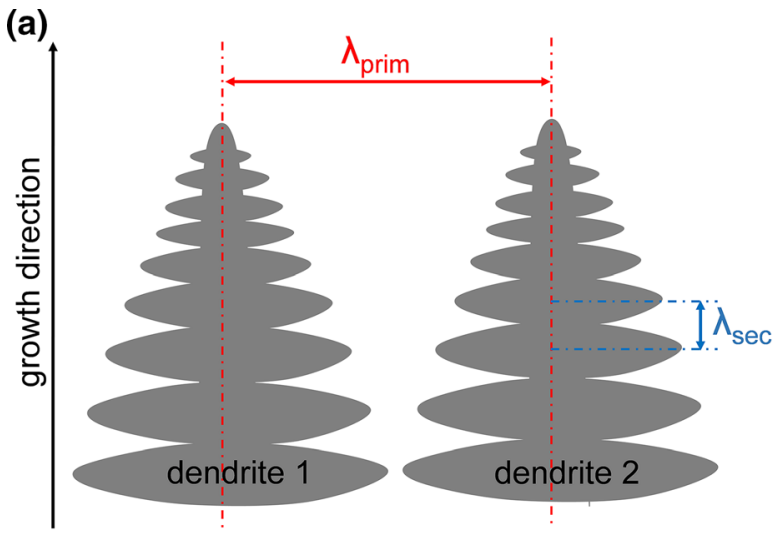

(b) Longitudinal section method

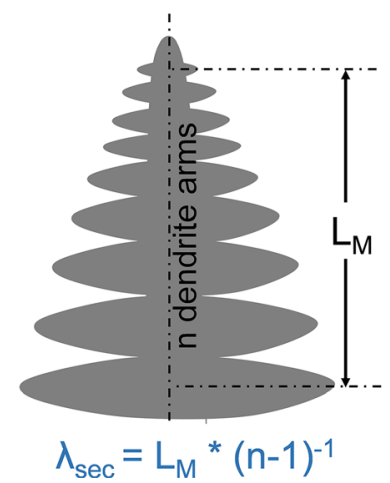

Fig. 3 (a) Schematic drawing of two dendrite trunks. The mean primary dendrite spacing $\left(\lambda_{\text {prim }}\right)$ and the mean secondary dendrite spacing $\left(\lambda_{\mathrm{sec}}\right)$ are marked in red and blue, respectively. (b) Schematic presentation of the linear intercept method to determine $\lambda_{\text {sec }}$ from a longitudinal dendrite cross section

For the measurement of $\lambda_{\text {prim }}$ and $\lambda_{\text {sec }}$, the LOM pictures were taken with a magnification factor of 50 and 100 , respectively. Figure 3(a) shows a schematic drawing of the definition of $\lambda_{\text {prim }}$ and $\lambda_{\mathrm{sec}}$. It has to be emphasized that $\lambda_{\text {prim }}$ corresponds to the dendrite trunk spacing and $\lambda_{\mathrm{sec}}$ corresponds to the primary dendrite arm spacing (Ref 33). As the dendrites are oriented approximately parallel to the etched cross section, the evaluation of $\lambda_{\text {prim }}$ and $\lambda_{\mathrm{sec}}$ was conducted with the linear intercept method using Olympus Stream Motion image processing software. Here, a line is placed normal to a number of $\mathrm{n}$ primary or secondary dendrites, which reaches from the middle of the first dendrite to the middle of the $n^{\text {th }}$ dendrite. The mean dendrite spacing is then calculated by dividing the length of this measurement line by the number of crossed dendrites $\mathrm{n}$ minus 1 (Ref 34). The graphic in Fig. 3(b) schematically shows how $\lambda_{\text {sec }}$ is determined from the LOM images using the linear intercept method. For each specimen and etchant, more than 200 primary and secondary dendrites were analyzed to determine the mean dendrite spacings $\lambda_{\text {prim }}$ and $\lambda_{\text {sec}}$.

Macro-images of the Nital $\left(3 \% \mathrm{HNO}_{3}\right.$ in ethanol) etched weld metals were taken in order to investigate the influence of the heat input on the size of the weld beads.

For the determination of the prior austenite grain size, the all-weld specimens were heat treated at $700{ }^{\circ} \mathrm{C}$ for $10 \mathrm{~h}$, ground, polished and etched with Béchet-Beaujard etchant. Ten LOM dark field images were taken in the HAZ between the last and the subjacent weld bead (magnification of 500) and in the last weld metal (magnification of 200) of each all-weld metal specimen. The grain size analysis was conducted with an Olympus Stream Motion image processing software using the linear intercept method. Therefore, a pattern of ten horizontal measurement lines was chosen and the points of intersection with prior austenite grain boundaries were set manually for each LOM image.

\subsection{Scanning Electron Microscopy Analysis}

A scanning electron microscope (SEM) equipped with a FEI Versa 3D Dual DualBeam and an electron backscatter diffraction (EBSD) system from EDAX Hikari XP was used to investigate the microstructure within the last weld bead, see Fig. 2.

Additionally, S and P distribution mappings of weld metal D were performed with a Cameca SX 100 micro-probe with five spectrometers. In order to investigate a cross section with a sufficient number of primary dendrite trunks, an area of 256 times $256 \mu^{2}$ was analyzed using a step size of $2.5 \mu \mathrm{m}$ and $80 \mathrm{~ms}$ dwell time. The acceleration voltage was $15 \mathrm{kV}$. The allweld metal specimen was in the as-welded state without any heat treatment.

For EBSD experiments, the specimens were ground and polished with diamond suspension ( 3 and $1 \mu \mathrm{m}$ ) and etched with Nital before the final polishing step using Struers OP-S colloidal Si suspension. The specimen tilt was $70^{\circ}$, the scanning mode was analytical mode, the working distance was $17 \mathrm{~mm}$, the acceleration voltage was set to $30 \mathrm{kV}$, the step size was $0.2 \mu \mathrm{m}$, and $6 \times 6$ binning was used. To determine the bainitic grain size, an area of $160 \times 160 \mu \mathrm{m}^{2}$ was mapped to ensure the analysis of a sufficient number of grains. The evaluation of the EBSD scans was conducted with the software OIM data Analysis 8 (EDAX inc.) and Origin Pro 2017G.

\subsection{Mechanical Testing}

One sample for tensile testing according to DIN EN ISO 5178:2019 (Ref 35) and five Charpy V-notch impact testing samples according to DIN EN ISO 148-1:2009 (Ref 36) were machined out of the four welded joints. The tensile specimens were taken from the middle of the weld seam with the longitudinal axis in welding direction (all-weld metal specimens), and the Charpy V-notch specimens were machined out normal to the welding direction (cross-weld specimens). According to DIN EN ISO 9016:2012 (Ref 37), the position of the V-notch was VWT 0/7.0 which means that the notch was located in the middle of the weld metals cross section where the left and right weld beads overlap. Before mechanical testing, the weld metals did undergo a dehydrogenation treatment (soaking at $350{ }^{\circ} \mathrm{C}$ for $4 \mathrm{~h}$ ). To relief the stresses from the welding operation, the weld metals for the tensile test were post-weld heat treated at $705^{\circ} \mathrm{C}$ for $8 \mathrm{~h}$ before they were machined and tested at room temperature. The Charpy V-notch specimens from the same heat-treated weld metals were tested at $-30{ }^{\circ} \mathrm{C}$.

Additionally, Vickers hardness measurements were conducted on the all-weld metal specimens after a PWHT of 8 and $32 \mathrm{~h}$ at $705{ }^{\circ} \mathrm{C}$, respectively. Ten HV10 macro-hardness indents were made on a line in vertical and horizontal direction on the weld metal cross sections. 

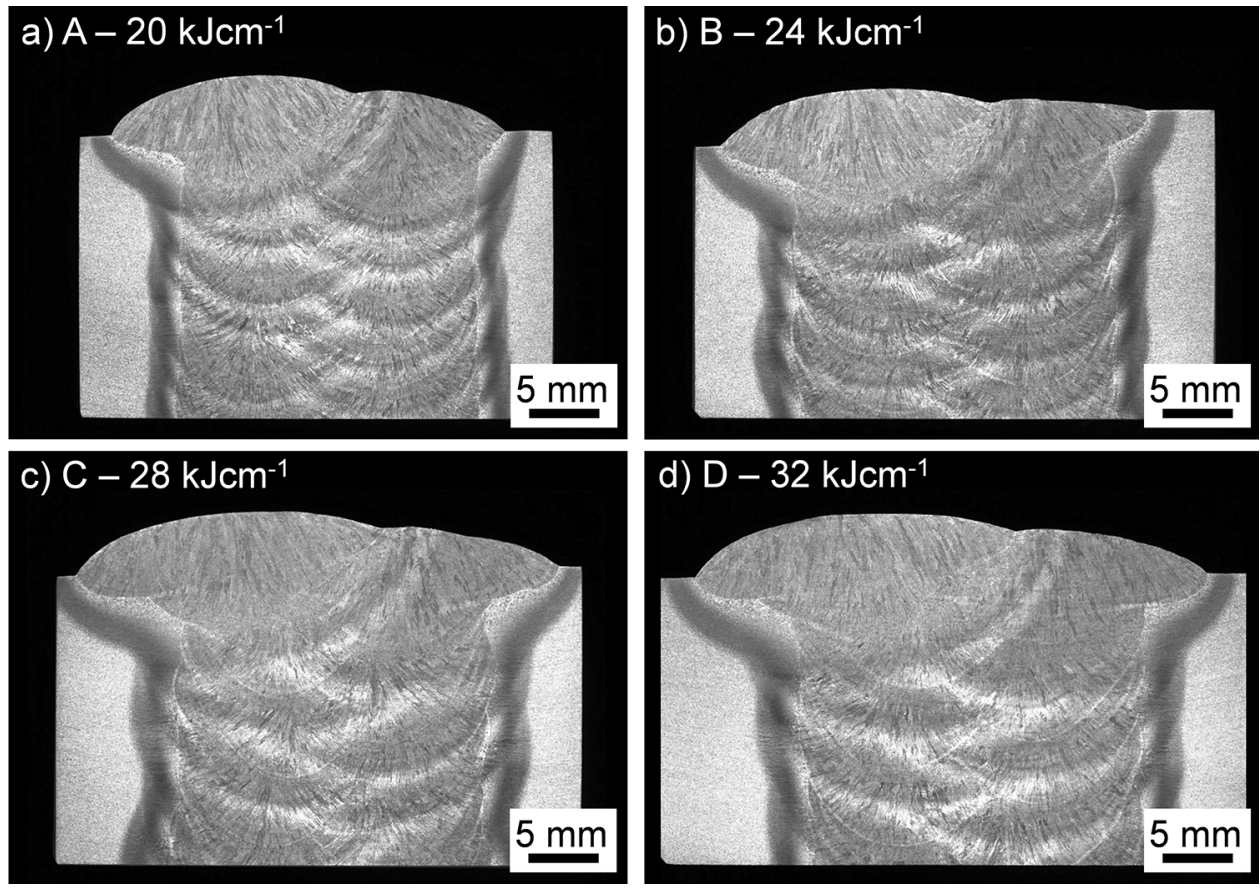

Fig. 4 Macro-images of the all-weld metals bead sequence etched with Nital and welded with a heat input of (a) $20 \mathrm{~kJ} \mathrm{~cm}^{-1}$, (b) $24 \mathrm{~kJ} \mathrm{~cm}{ }^{-1}$, (c) $28 \mathrm{~kJ} \mathrm{~cm}^{-1}$ and (d) $32 \mathrm{~kJ} \mathrm{~cm}^{-1}$

According to ASME Boiler and Pressure Vessel Code Section VIII Division 2:2017 (Ref 38), stress rupture tests were conducted at $540{ }^{\circ} \mathrm{C}$ and $210 \mathrm{MPa}$. All stress rupture tests were performed after a PWHT at $705{ }^{\circ} \mathrm{C}$ and an annealing time of 32 h.

\section{Results}

\subsection{Weld Metal Microstructure}

3.1.1 Light Optical Microscopy. Figure 4 shows macroimages of the Nital etched weld seam cross sections produced with different heat inputs of $20,24,28$ and $32 \mathrm{~kJ} \mathrm{~cm}^{-1}$. The images reveal that a higher heat input during SAW leads to larger sized weld beads which, in further consequence, results in a reduced amount of layers for welding of the same weld gap width (similar amount of welded volume). In addition, the weld metal and the partially melted zone of the base metal broaden with increase in heat input during welding.

Figure 5 exemplarily shows LOM images of the cross section of the Nital etched all-weld metal specimen D. One can see that the weld beads consist of columnar prior austenite grains which are aligned in the direction of heat flow during welding, whereas the HAZs between the weld beads and the $\mathrm{HAZ}$ to the base metal exhibit a much finer equiaxed prior austenite grain structure.

Figure 6 provides a comparison of the microstructure within the last weld bead of the as-welded specimens produced with $20 \mathrm{~kJ} \mathrm{~cm}^{-1}$ (Fig. 6a) and $32 \mathrm{~kJ} \mathrm{~cm}^{-1}$ heat input (Fig. 6b). Both weld metals exhibit upper bainitic microstructures which appear to be very similar. Despite the higher heat input of $32 \mathrm{~kJ} \mathrm{~cm}^{-1}$ of weld metal specimen $\mathrm{D}$ and the considerably longer $t_{8 / 5}$-time (see Table 2), the microstructure did not change significantly and no ferrite formation was noticed. The microstructures within the HAZ between the last weld bead and the subjacent weld bead are also fully upper bainitic for all investigated weld metal specimens. This is in accordance with prior studies on the change of the $2.25 \mathrm{Cr}-1 \mathrm{Mo}-0.25 \mathrm{~V}$ weld metals microstructure by varying cooling rates, where ferrite formation was only detected for $t_{8 / 5}$-times higher than $100 \mathrm{~s}$ (Ref 39).

Figure 7 shows the average prior austenite grain size number according to ASTM-G (ASTM E112-10) (Ref 40) and the average prior austenite grain size in $\mu \mathrm{m}$ determined using the linear intercept method. The prior austenite grain size of the last weld bead equals the width of the columnar prior austenite grains. One can see that in both areas, the last weld bead and the HAZ between the last weld bead and the subjacent one, the prior austenite grain size increases with higher heat input during SAW (equals decreasing ASTM-G grain size number). Nevertheless, the prior austenite grain size of the last weld bead only increases up to weld metal $\mathrm{C}$ with a heat input of $28 \mathrm{~kJ} \mathrm{~cm}^{-1}$ and stays nearly constant for weld metal D which was welded with the highest heat input of $32 \mathrm{~kJ} \mathrm{~cm}^{-1}$. Furthermore, the prior austenite grain size in the HAZ, between the last and the subjacent weld bead, is considerably smaller than the prior austenite grain size in the last weld bead, for all investigated heat inputs.

Figure 8 displays the dendritic solidification structure of specimen D welded with $32 \mathrm{~kJ} \mathrm{~cm}^{-1}$ heat input after treatment with Béchet-Beaujard etchant. Both mean dendrite spacings $\lambda_{\text {prim }}$ and $\lambda_{\text {sec }}$ can be contrasted well in the LOM after etching.

The results of the determination of the mean dendrite spacings $\lambda_{\text {prim }}$ and $\lambda_{\text {sec }}$ are presented in Fig. 9. $\lambda_{\text {prim }}$ as well as $\lambda_{\text {sec }}$ increases with higher heat input which is in accordance with the calculated $t_{8 / 5}$-times of the last weld beads. A higher heat input during SAW which was practically obtained by decreasing the welding speed causes a nearly linear rise of the $t_{8 / 5}$-time and hence a decline of the cooling rate. Additionally, 

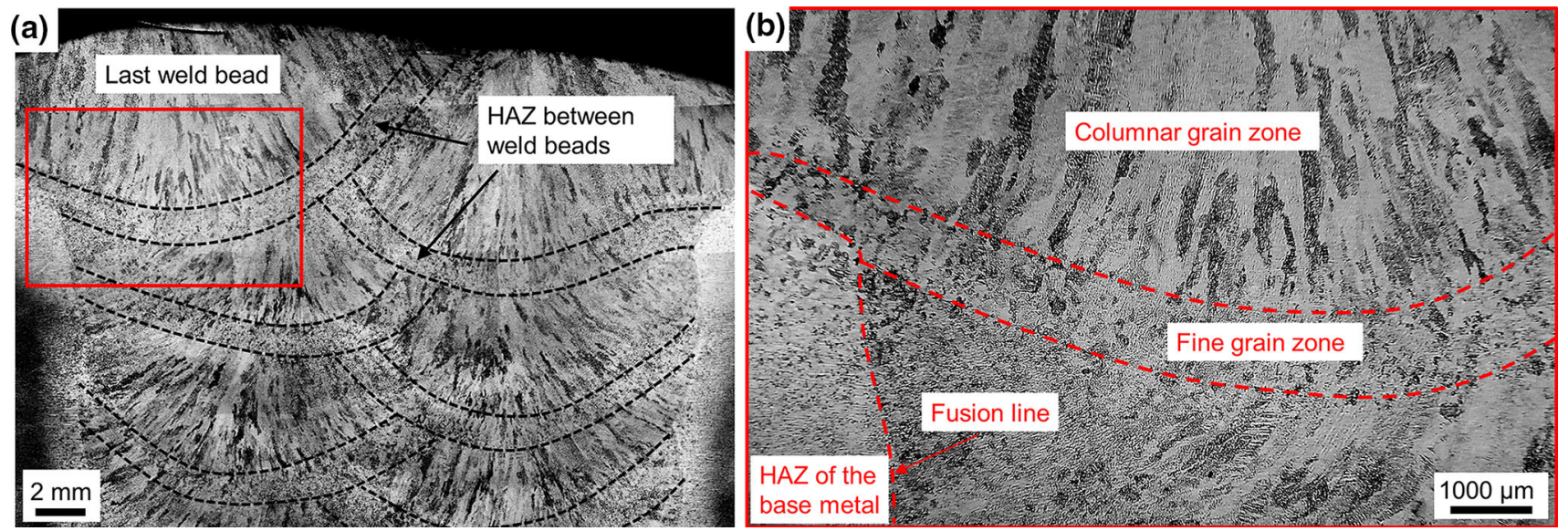

Fig. 5 LOM images of specimen D welded with $32 \mathrm{~kJ} \mathrm{~cm}^{-1}$ showing (a) an overview of the bead sequence and (b) a section with higher magnification exhibiting the differences in grain size and morphology
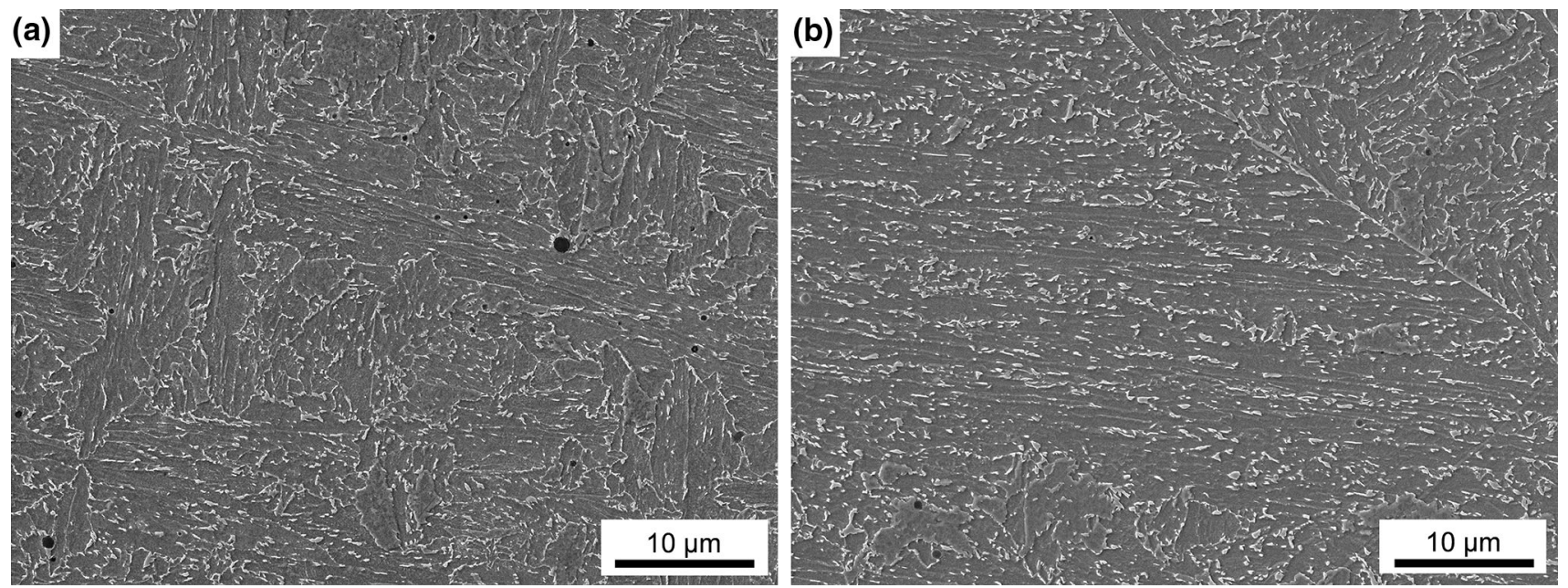

Fig. 6 SEM images of the Nital etched as-welded microstructure within the last weld bead of (a) weld metal A (20 kJ $\mathrm{cm}^{-1}$ heat input) and (b) weld metal $\mathrm{D}\left(32 \mathrm{~kJ} \mathrm{~cm}^{-1}\right.$ heat input)

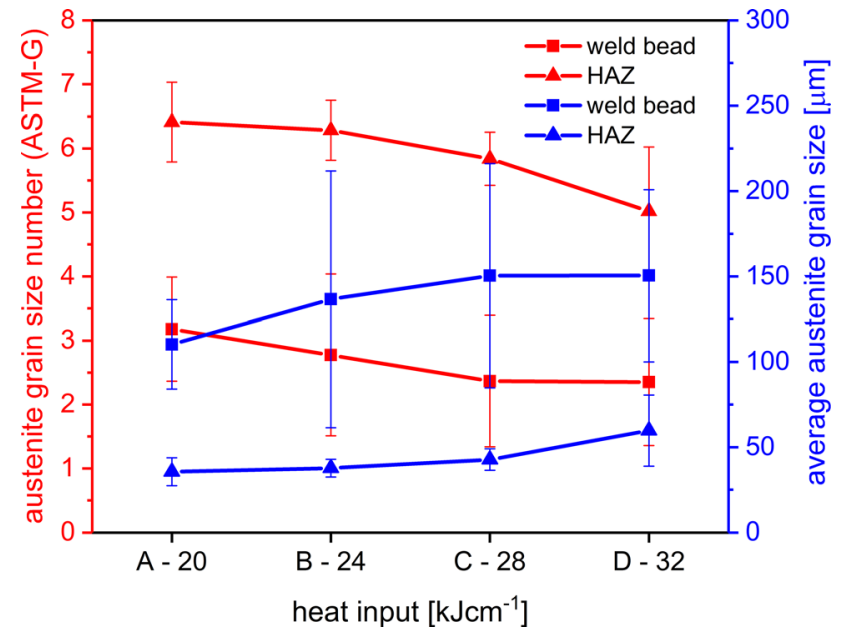

Fig. 7 Average prior austenite grain size and average grain size number in the last weld bead and the HAZ between the last and subjacent weld bead of the four all-weld metal specimens A to D. The grain sizes were determined using the linear intercept method, according to ASTM-G.

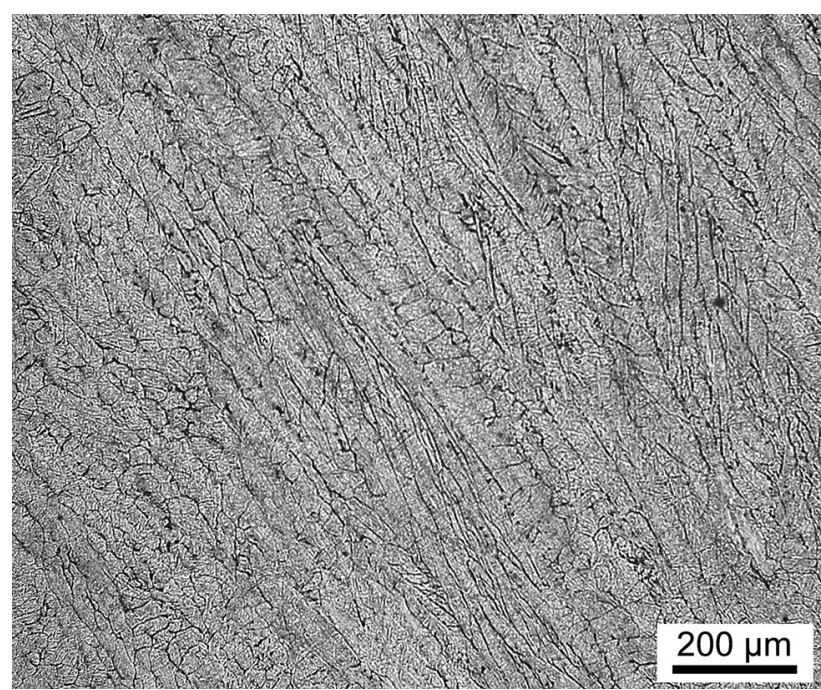

Fig. 8 LOM image of the dendritic solidification structure of specimen D welded with $32 \mathrm{~kJ} \mathrm{~cm}^{-1}$ heat input after treatment with Béchet-Beaujard etchant 


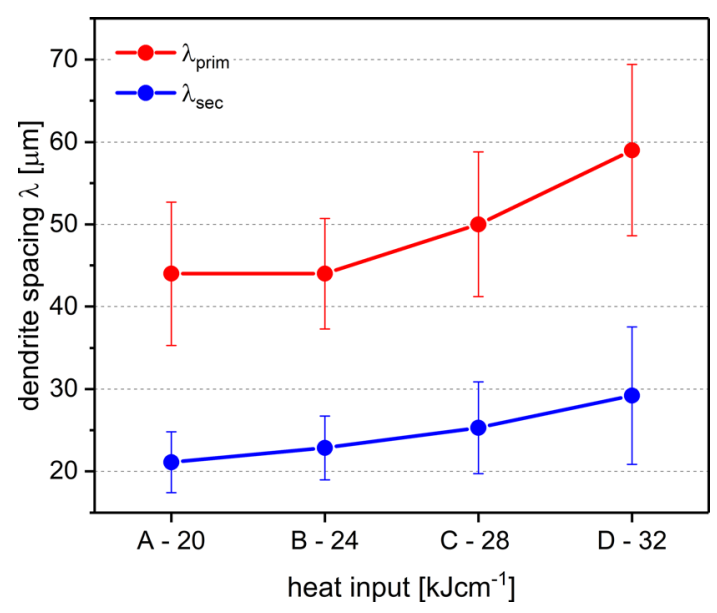

Fig. 9 Mean dendrite spacings $\lambda_{\text {prim }}$ and $\lambda_{\text {sec }}$ as a function of the applied heat input during SAW the analysis of the dendrite spacings revealed that the relation of $\lambda_{\text {prim }}$ to $\lambda_{\text {sec }}$ lies between a factor of 2 to 3 .

3.1.2 Electron backscatter diffraction. Figure 10 shows sections of inverse pole figures maps (IPF) which were used for the analysis of the bainitic grain size by means of EBSD. The IPF maps are superimposed with the high-angle grain boundaries exceeding misorientation angles greater than $15^{\circ}$. By comparing Fig. 10(a) (weld metal $\mathrm{A}-20 \mathrm{~kJ} \mathrm{~cm}^{-1}$ heat input) and Fig. 10(b) (weld metal D-32 kJ cm ${ }^{-1}$ heat input), one can see that a higher heat input during welding leads to a coarser bainitic grain size in both investigated areas, the last weld bead and the HAZ between the last weld bead and the subjacent one. Furthermore, the bainitic grain size of the HAZ below the last weld bead appears to be finer than the bainitic grain size of the last weld bead. Additionally, the microstructure of the weld metal with the highest heat input of $32 \mathrm{~kJ} \mathrm{~cm}^{-1}$ (Fig. 10b) seems to have a bimodal grain size distribution consisting of coarser elongated grains with many smaller grains in-between.

Figure 11 presents the related bainitic grain size distributions and the cumulative fraction of grain sizes belonging to the

(a) $\mathrm{A}-20 \mathrm{kJcm}^{-1}$

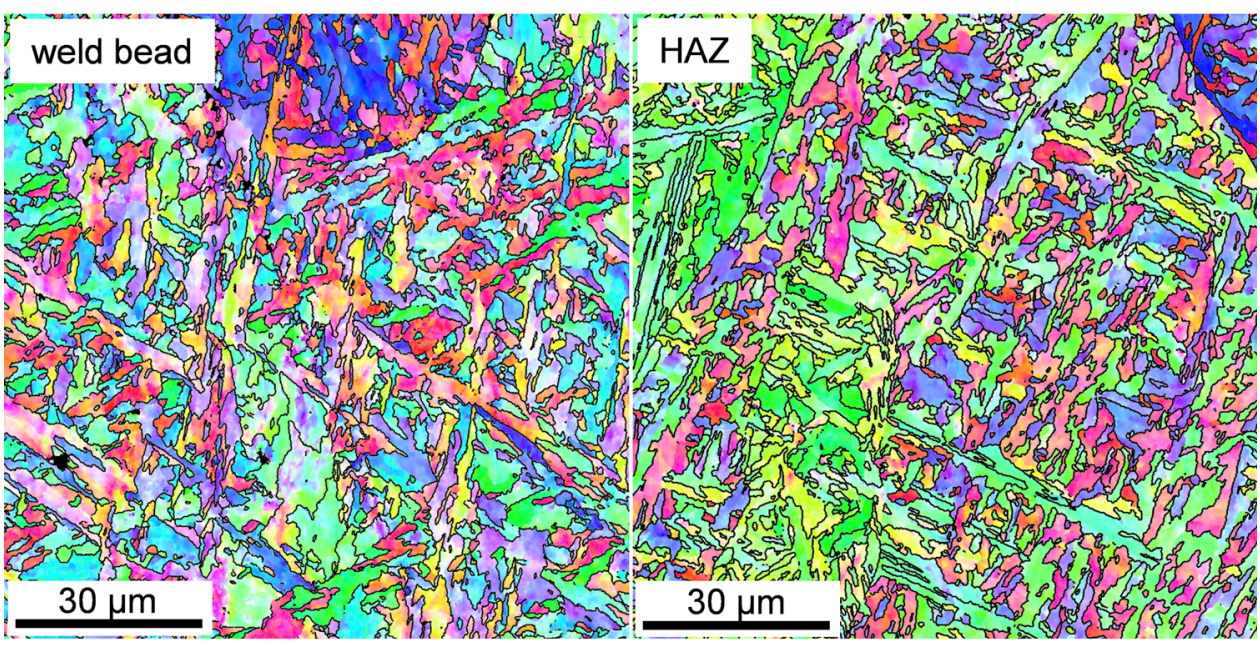

(b) $\mathrm{D}-32 \mathrm{kJcm}^{-1}$

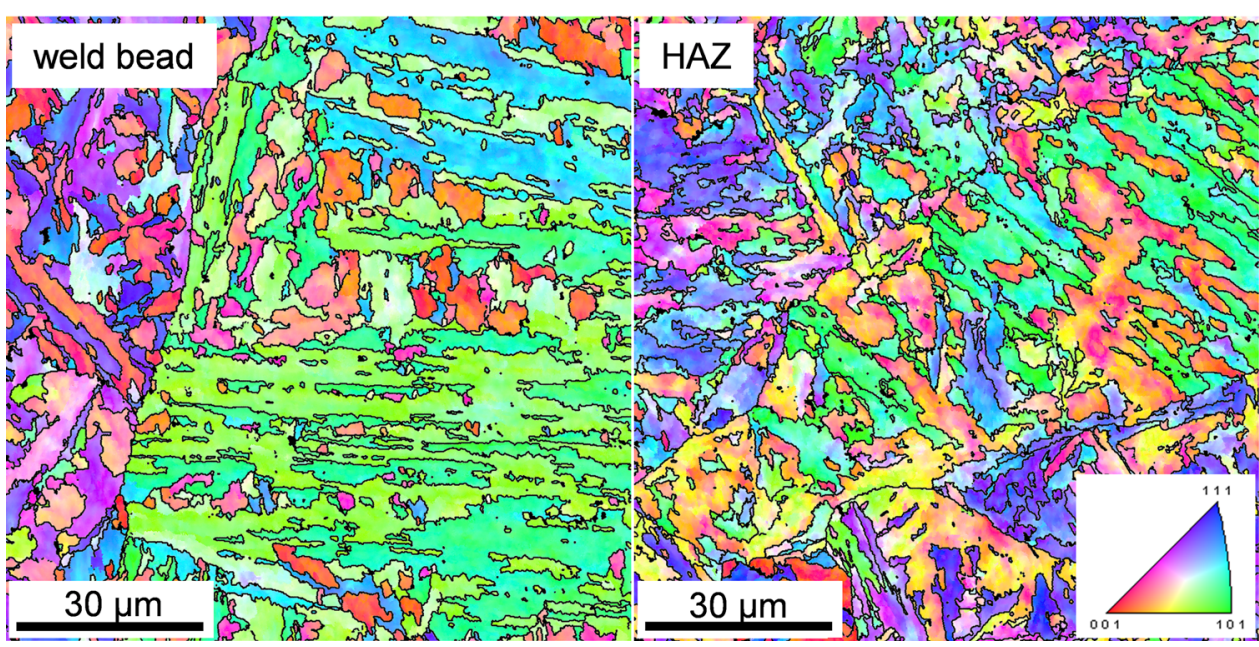

Fig. 10 Sections of the inverse pole figure (IPF) maps obtained by EBSD analysis superimposed with high-angle grain boundaries of (a) specimen $\mathrm{A}\left(20 \mathrm{~kJ} \mathrm{~cm}^{-1}\right.$ heat input) and (b) specimen $\mathrm{D}\left(32 \mathrm{~kJ} \mathrm{~cm}^{-1}\right.$ heat input) used for the bainitic grain size analysis. The IPF maps on the left side show a region within the last weld bead and the IPF maps on the right side a region within the HAZ between the last weld bead and the subjacent weld bead, respectively. 

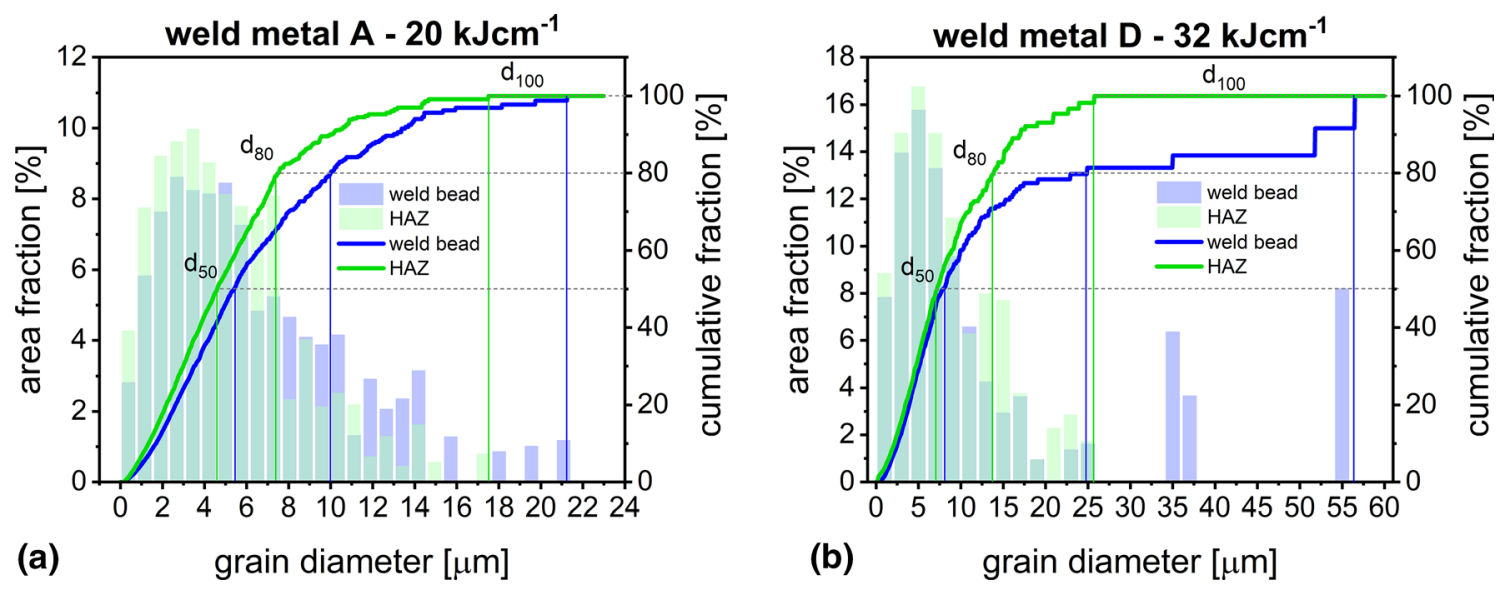

Fig. 11 Bainitic grain size distributions and the corresponding cumulative fractions of the bainitic grain sizes with the $d_{50}, d_{80}$ and $d_{100}$ value of the area within the last weld bead and the area within the HAZ between the last and the subjacent weld bead for (a) weld metal A (20 $\mathrm{kJ} \mathrm{cm}^{-1}$ heat input) and (b) weld metal $\mathrm{D}\left(32 \mathrm{~kJ} \mathrm{~cm}^{-1}\right.$ heat input)

IPFs shown in Fig. 10. For weld metal A, the cumulative fraction of the grain sizes in the HAZ between the weld beads reaches $50 \%$ at a grain size of $4.7 \mu \mathrm{m}, 80 \%$ at a grain size of $7.4 \mu \mathrm{m}$ and $100 \%$ at a grain size of $17.6 \mu \mathrm{m}$, whereas the cumulative fraction of the grain sizes in the last weld bead reaches $50 \%$ at a grain size of $5.5 \mu \mathrm{m}, 80 \%$ at a grain size of $10 \mu \mathrm{m}$ and $100 \%$ at a grain size of approximately $21.2 \mu \mathrm{m}$. In contrast, for weld metal $\mathrm{D}$, the cumulative fraction of the grain sizes in the HAZ reaches $50 \%$ at a grain size of $7.1 \mu \mathrm{m}$, $80 \%$ at a grain size of $13.7 \mu \mathrm{m}$ and $100 \%$ at $25.7 \mu \mathrm{m}$, whereas the cumulative fraction of the grain sizes in the much coarser weld bead reaches $50 \%$ at a grain size of $8.1 \mu \mathrm{m}, 80 \%$ at a grain size of $24.8 \mu \mathrm{m}$ and $100 \%$ at $56.3 \mu \mathrm{m}$. So for both presented all-weld metal specimens in Fig. 11, the bainitic grain size is larger in the last weld bead than in the HAZ between the last and the subjacent weld bead. Furthermore, the bainitic grain size is considerably larger for weld metal D, which was fabricated with a heat input of $32 \mathrm{~kJ} \mathrm{~cm}^{-1}$, than for weld metal A, which was welded with a lower heat input of $20 \mathrm{~kJ} \mathrm{~cm}^{-1}$.

Figure 12 presents the $d_{50}, d_{80}$ and $d_{\text {mean }}$ values of the bainitic grain size determined from the EBSD data using the software OIM data Analysis 8. All four investigated all-weld metal specimens exhibit a larger bainitic grain size in the last weld bead than in the HAZ between the last and the subjacent weld bead. Furthermore, an increase in heat input during SAW of $2.25 \mathrm{Cr}-1 \mathrm{Mo}-0.25 \mathrm{~V}$ steel leads to an increase in the mean bainitic grain size in both investigated areas, the last weld bead and the HAZ between the last and the subjacent weld bead, see difference in $d_{50}, d_{80}$ and $d_{\text {mean }}$ values of weld metal A $\left(20 \mathrm{~kJ} \mathrm{~cm}^{-1}\right)$ to weld metal D $\left(32 \mathrm{~kJ} \mathrm{~cm}^{-1}\right)$ in Fig. 12.

3.1.3 Micro-Probe Analysis. The investigation of the interdendritic segregations by means of micro-probe analysis of weld metal D (32 $\mathrm{kJ} \mathrm{cm}^{-1}$ heat input), which was expected to show the most pronounced segregations, revealed that the impurity elements $\mathrm{P}$ and $\mathrm{S}$ vary only slightly across the dendritic solidification structure, see Fig. 13. The element distribution maps reveal a slightly higher number of counts every 50 to $60 \mu \mathrm{m}$, which equals the determined primary dendrite spacing (distance between dendrite trunks) of all-weld metal specimen D; however, these slight variations are not considered to be significant.

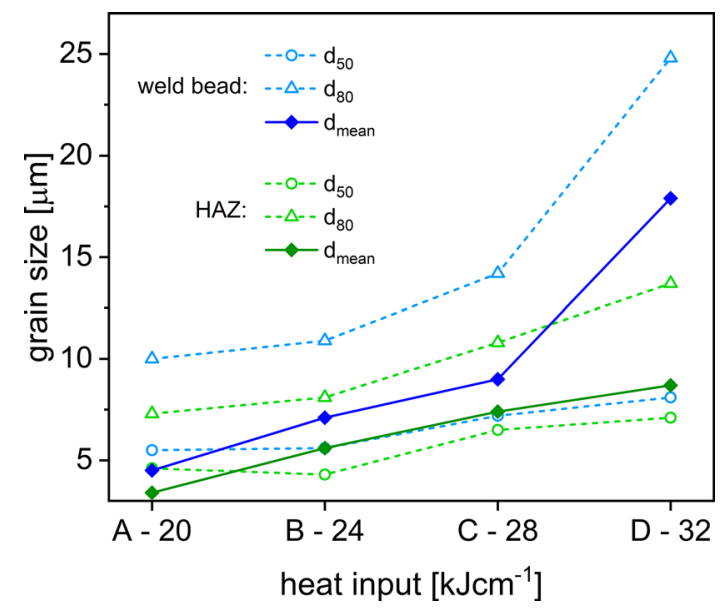

Fig. $12 d_{50}, d_{80}$ and $d_{\text {mean }}$ values of the bainitic grain size of the last weld bead and the HAZ between the last and the subjacent weld bead of weld metal A $\left(20 \mathrm{~kJ} \mathrm{~cm}^{-1}\right.$ heat input) to weld metal $\mathrm{D}$ (32 $\mathrm{kJ} \mathrm{cm}^{-1}$ heat input) determined from EBSD data

\subsection{Mechanical Properties and Hardness}

Figure 14 shows the results of the HV10 macro-hardness measurements in horizontal and vertical direction of the allweld metal specimens produced with different heat inputs of $20,24,28$ and $32 \mathrm{~kJ} \mathrm{~cm}^{-1}$. The specimens were heat treated at $705^{\circ} \mathrm{C}$ for 8 and $32 \mathrm{~h}$, respectively. Although the hardness values show some deviations depending on the position of the indent on the weld metals cross section, there appears to be no connection between the macro-hardness and the heat input during SAW. Nonetheless, it can be seen that the PWHT-time has a major impact on the macro-hardness of the weld metal. After a short PWHT-time of $8 \mathrm{~h}$, the hardness of the all-weld samples is significantly higher than after the longer PWHT-time of $32 \mathrm{~h}$.

Tensile tests at room temperature and Charpy V-notch impact tests at $-30{ }^{\circ} \mathrm{C}$ were conducted for each of the four weld metal specimens. Figure 15(a) reveals that there is no significant change of the $0.2 \%$-yield strength (YS) and the 

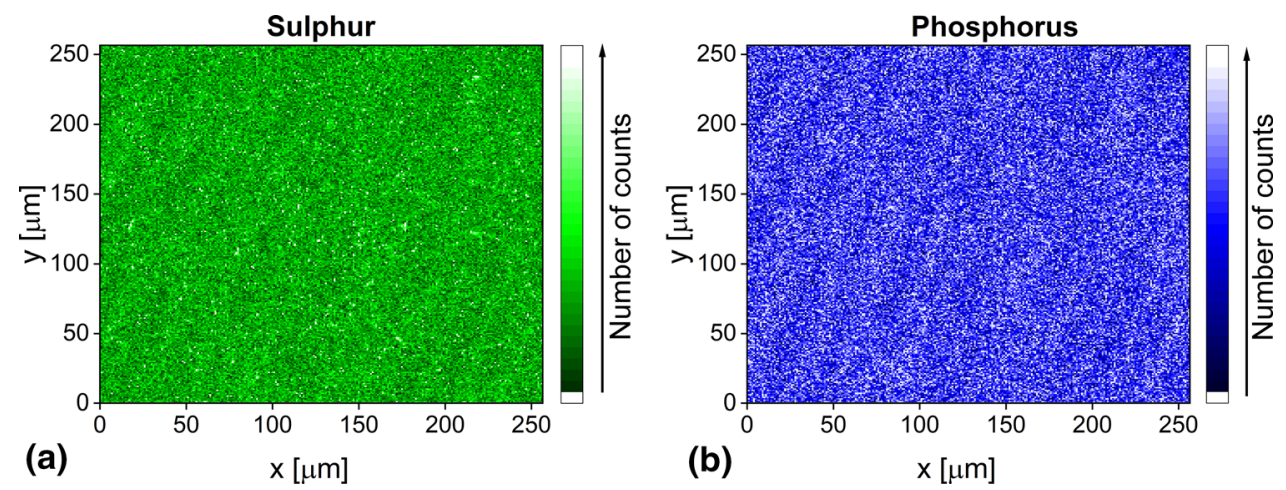

Fig. 13 (a) Qualitative P distribution and (b) qualitative S distribution determined via microprobe analysis

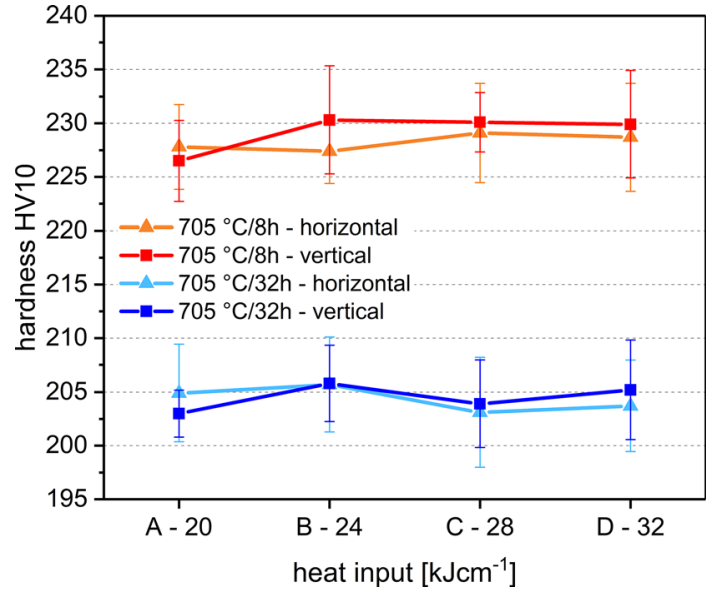

Fig. 14 Mean macro-hardness HV10 in horizontal and vertical direction on the all-weld metals cross sections as a function of the heat input and PWHT-time at $705{ }^{\circ} \mathrm{C}$

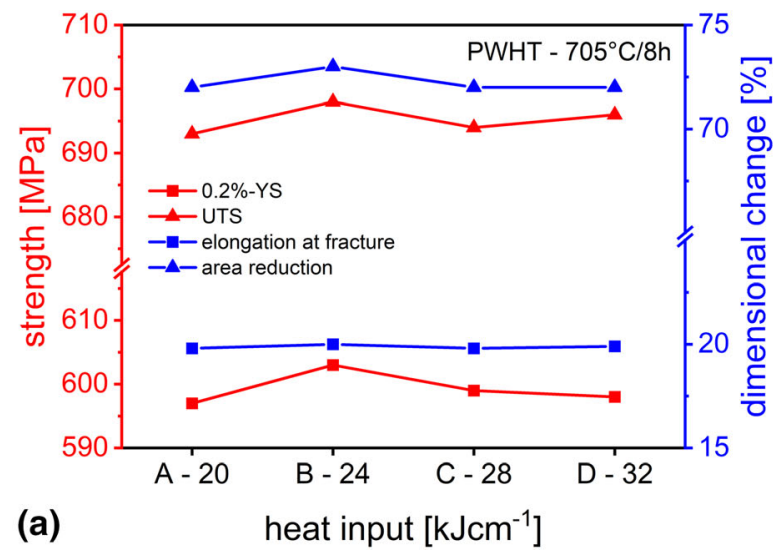

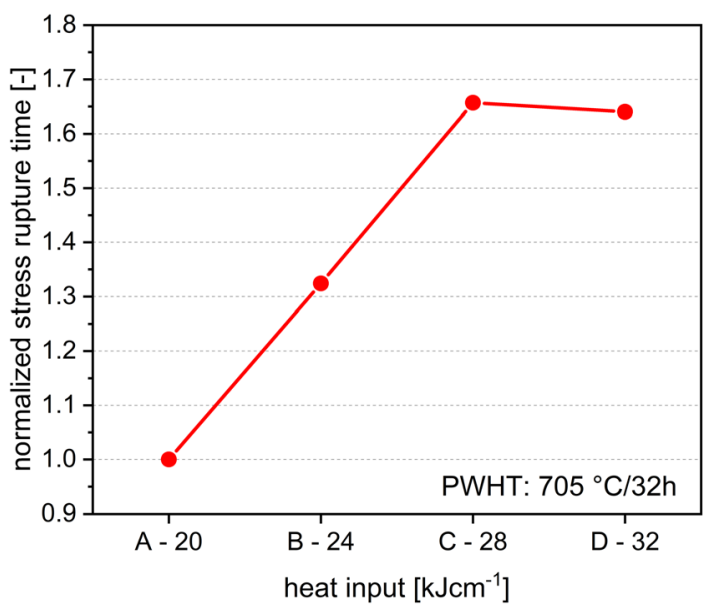

Fig. 16 Normalized stress rupture time versus heat input during SAW after a PWHT of $32 \mathrm{~h}$ at $705^{\circ} \mathrm{C}$

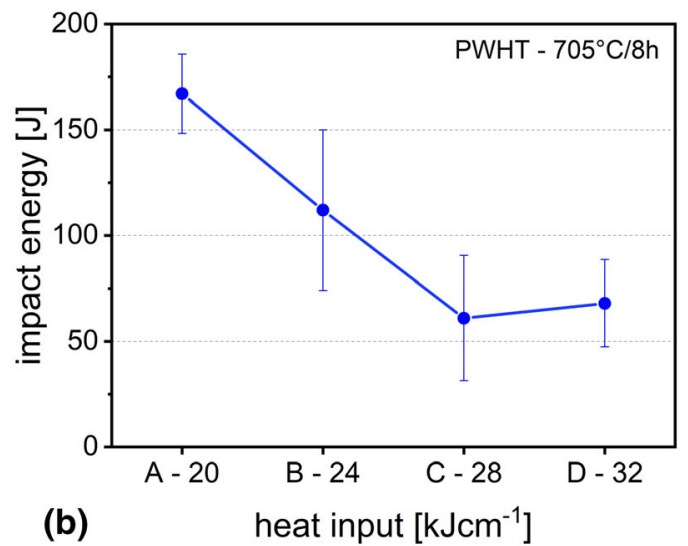

Fig. 15 (a) $0.2 \%$-YS, UTS, elongation at fracture and area reduction versus heat input during SAW and (b) Charpy impact energy versus heat input during SAW

ultimate tensile strength (UTS) with increase in heat input during welding. No correlation between elongation at fracture and reduction of area with the heat input was found either. Figure 15(b) shows that even though there is no influence of the heat input on the ductility of the weld metal, the heat input strongly influences the weld metal's toughness. After a PWHT of $8 \mathrm{~h}$ at $705{ }^{\circ} \mathrm{C}$, a strong decrease in impact energy with increase in heat input from 20 to $28 \mathrm{~kJ} \mathrm{~cm}^{-1}$ was observed. Concerning the range from 28 to $32 \mathrm{~kJ} \mathrm{~cm}^{-1}$, the impact toughness remains nearly constant. 


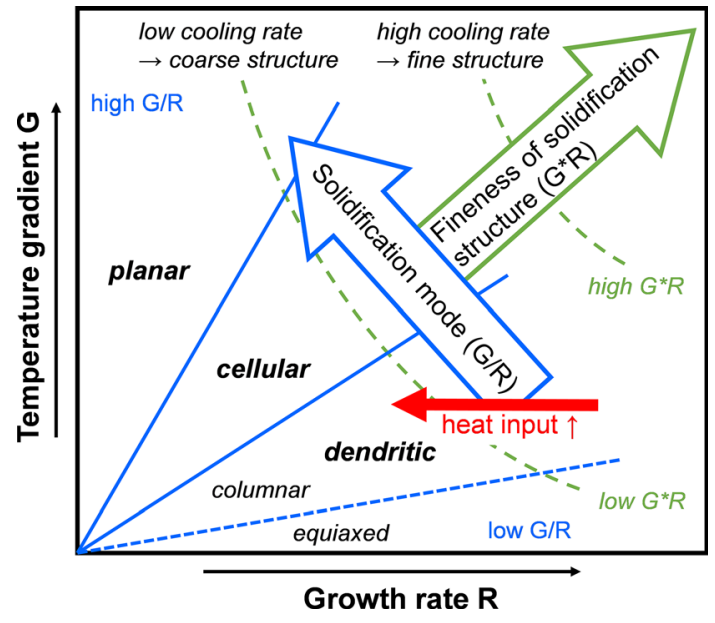

Fig. 17 Modified schematic drawing of the effect of temperature gradient $G$ and growth rate $R$ on the weld metals solidification structure adapted from Kou (Ref 14), Lippold (Ref 41) and Messler (Ref 15)

\subsection{Stress Rupture Behavior}

Figure 16 shows the normalized stress rupture time of the all-weld metal specimens A to D versus the heat input during SAW. The normalized stress rupture time equals the stress rupture time of the respective all-weld metal specimen divided by the minimum stress rupture time of the whole data set. With increase in heat input, the stress rupture time increases linearly between weld metal A (20 kJ cm ${ }^{-1}$ heat input) and weld metal $\mathrm{C}\left(28 \mathrm{~kJ} \mathrm{~cm}^{-1}\right.$ heat input). A further increase in heat input from 28 to $32 \mathrm{~kJ} \mathrm{~cm}^{-1}$ (weld metal D) did not lead to a further enhancement of the stress rupture time. The behavior of stress rupture time and Charpy impact energy is reverse; with higher heat input during SAW the stress rupture time increases and the Charpy impact energy decreases simultaneously. Between 28 and $32 \mathrm{~kJ} \mathrm{~cm}^{-1}$ heat input, both the impact energy and the stress rupture time stay nearly constant.

\section{Discussion}

\subsection{Influence of the Heat Input on the Dendritic Solidification Structure}

The LOM investigation of the Béchet-Beaujard etched allweld metals fabricated with different heat inputs revealed that a higher heat input during SAW evokes a coarser dendritic solidification structure. Even though the change in heat input was only moderate, it affected both mean dendrite spacings $\lambda_{\text {prim }}$ and $\lambda_{\text {sec }}$.

The increase in dendrite spacing with higher heat input during welding is a consequence of the lowered cooling rate which is defined as the product of temperature gradient $G$ and growth rate $R$, see green arrow in schematic drawing in Fig. 17 (Ref 14, 15, 41).

This decrease in cooling rate $(G * R)$ with increase in heat input leads to a prolonged solidification time and thus more time for diffusion. Furthermore, a longer solidification time enables the reduction of surface energy via the growth of larger dendrite arms at the expense of smaller dendrite arms which exhibit more surface area per unit volume (Ref 14, 15). The relatively high standard deviation of the determined mean dendrite arm spacings $\lambda_{\text {prim }}$ and $\lambda_{\mathrm{sec}}$ is a result of the inhomogeneous distribution of cooling rates within the weld bead. This is due to the fact that the temperature gradient is higher at the fusion line than at the centerline of the weld bead and that vice versa the growth rate is much higher at the centerline compared to the fusion line of the weld bead. Therefore, the cooling rate is highest at the weld beads centerline and lowest at the fusion line and changes gradually between these lines. As a consequence, the solidification structure is the finest in welding direction and gets enlarged with increase in distance from the weld metals centerline, leading to a variety of dendrite spacings within a single weld bead caused by local changes in the cooling rate (Ref 14).

Further on, the different heat inputs during SAW did not lead to a significant alteration of the ratio $G / R$ within the last weld bead, as no change in solidification mode from columnar to equiaxed dendritic was visible via LOM investigation.

An increase in heat input during welding is known to possibly influence the local concentration of impurity elements such as $\mathrm{S}, \mathrm{P}$ or $\mathrm{B}$, which tend to segregate to the grain boundary during solidification. There, they can form compounds with low melting points which widen the solidification temperature range and lead to an increased mushy zone which is prone to solidification cracking ( $\operatorname{Ref} 14,15,41,42)$. The lower the content of these residual elements is and the more homogeneous they are distributed within the grain or sub-grain area; the less harmful they are and the lower is the risk of solidification cracking (Ref 15 ). The analysis of the $2.25 \mathrm{Cr}$ $1 \mathrm{Mo}-0.25 \mathrm{~V}$ all-weld metal specimen produced with the highest heat input of $32 \mathrm{~kJ} \mathrm{~cm}^{-1}$ revealed that despite the broad solidification structure (increased dendrite spacing) still no significant variations of the $\mathrm{S}$ and $\mathrm{P}$ content were recognizable across the dendritic solidification structure by means of microprobe analysis. Therefore, it is assumed that increasing the heat input up to $32 \mathrm{~kJ} \mathrm{~cm}^{-1}$ by reducing the welding speed does not significantly increase the weld metals risk for solidification cracking.

\subsection{Influence of the Heat Input on the Microstructure and Mechanical Properties}

The tensile testing of the four all-weld metal samples revealed that despite the broader and thicker weld beads generated via welding with higher heat input, no influence on the strength and ductility was found.

In contrast, there was a strong correlation between the heat input during SAW and the weld metal's toughness. A lower heat input, realized by welding with higher welding speed, improves the weld metal's toughness. This effect can be attributed to the bead sequence consisting of a higher number of weld beads compared to a weld metal produced with a higher heat input. Each weld bead consists of a fine upper bainitic microstructure with large prior austenite grains which are elongated in the direction of the solidification (columnar grained zone). Between the individual weld beads of the multilayer weld, metal fine grained HAZs (equiaxed grained zone) have formed due to reheating by further weld beads throughout the welding process. A finer bainitic microstructure is beneficial for the weld metals toughness, as more interfaces provide more positions for stress and strain redistribution. Furthermore, the grain size analysis showed that the mean bainitic and prior austenite grain size increases with higher heat input during 
SAW for both investigated zones, the last weld bead and the HAZ.

While the average bainitic and prior austenite grain size was found to correlate with the heat input during SAW, the variation of heat input did not affect the microstructure constituents of the weld metals. Despite the broad range of $t_{8 / 5}$-times obtained by varying the heat input, the microstructure in the as-welded state was fully upper bainitic for the four investigated all-weld metal specimens. So the decrease in weld metal impact toughness with higher heat input cannot be attributed to the negative influence of a certain microstructure constituent which forms at lower cooling rates.

It is therefore concluded that solely the finer microstructure is responsible for the higher toughness when welding is performed with lower heat input. Weld metals produced with lower heat input consist of a higher number of weld layers with less thick weld beads. Hence, the microstructure changes more often between coarse grained weld beads and fine grained HAZs between these weld beads. As a result, the Charpy Vnotch specimens machined out of the weld metals produced with lower heat input contain a higher amount of fine grained HAZ per unit volume compared to the ones welded with higher heat input, see Fig. 18.

The higher proportion of fine grained zone and the finer bead sequence, which causes a more frequent change between coarse and fine grained microstructure, is beneficial for the weld metals toughness. Wenkai et al. (Ref 17) found a similar behavior during Charpy impact testing of narrow-gap metal active gas welded AISI 326LN ASS plates. They experienced that cross-weld specimens with the V-notch positioned in the cross section (normal to welding direction, many weld beads) absorbed more energy during Charpy testing than specimens with the V-notch on top of their surface (in welding direction, single weld bead). This anisotropy in the cryogenic impact performances was found for all investigated weld metals joined with different heat inputs and was explained by the anisotropic dendritic microstructure. However, for the submerged-arc weld metal investigated within this study, the effect of decreasing toughness with increase in heat input is not visible for weld metal D $\left(32 \mathrm{~kJ} \mathrm{~cm}^{-1}\right)$. This is assumed to be linked to its bead sequence which is similar to weld metal $\mathrm{C}\left(28 \mathrm{~kJ} \mathrm{~cm}^{-1}\right)$. Despite the higher heat input, weld metal D exhibits the same amount of weld layers as weld metal $C$, causing no significant difference of the amount of fine grained zones between these two specimens. The lacking difference in impact toughness of weld metal $\mathrm{C}$ and $\mathrm{D}$ leads to the assumption that the weld metal's bead sequence, and therefore, the change between coarse and fine grained zones is more decisive for the weld metals toughness than solely the bainitic grain size.

Nonetheless, when comparing Charpy impact energies, further influencing factors which are responsible for the relatively large scattering of the values should be discussed. In multilayer weld metal, the exact position of the V-notch shows great influence on the impact energy during Charpy Vnotch testing, see schematic drawing in Fig. 19. To eliminate the influence of a finer bead sequence, only Charpy V-notch specimens with the same heat input (same amount of weld layers) are compared in Fig. 19. Ideally, the V-notch should be positioned in the middle of the weld metal where the individual weld beads cross each other, see green mark in Fig. 19. Then, the notch lies in a zone, which was reheated several times and therefore exhibits a high amount of fine grained HAZs. Such a frequent change between fine and coarse grained regions has been proven to be beneficial for toughness. In comparison, if the notch lies right to the ideal position (red mark in Fig. 19), where the left and right weld beads do not cross, the amount of fine grained HAZ in the tested area is lower and there is a less frequent change between coarse grained weld beads and HAZs. Equally, when the notch lies left to the ideal position (blue mark in Fig. 19), the testing area also does not lie in the region of crossing weld beads anymore, and therefore, the amount of fine grained HAZ again is lower, which has also a decreasing effect

High heat input
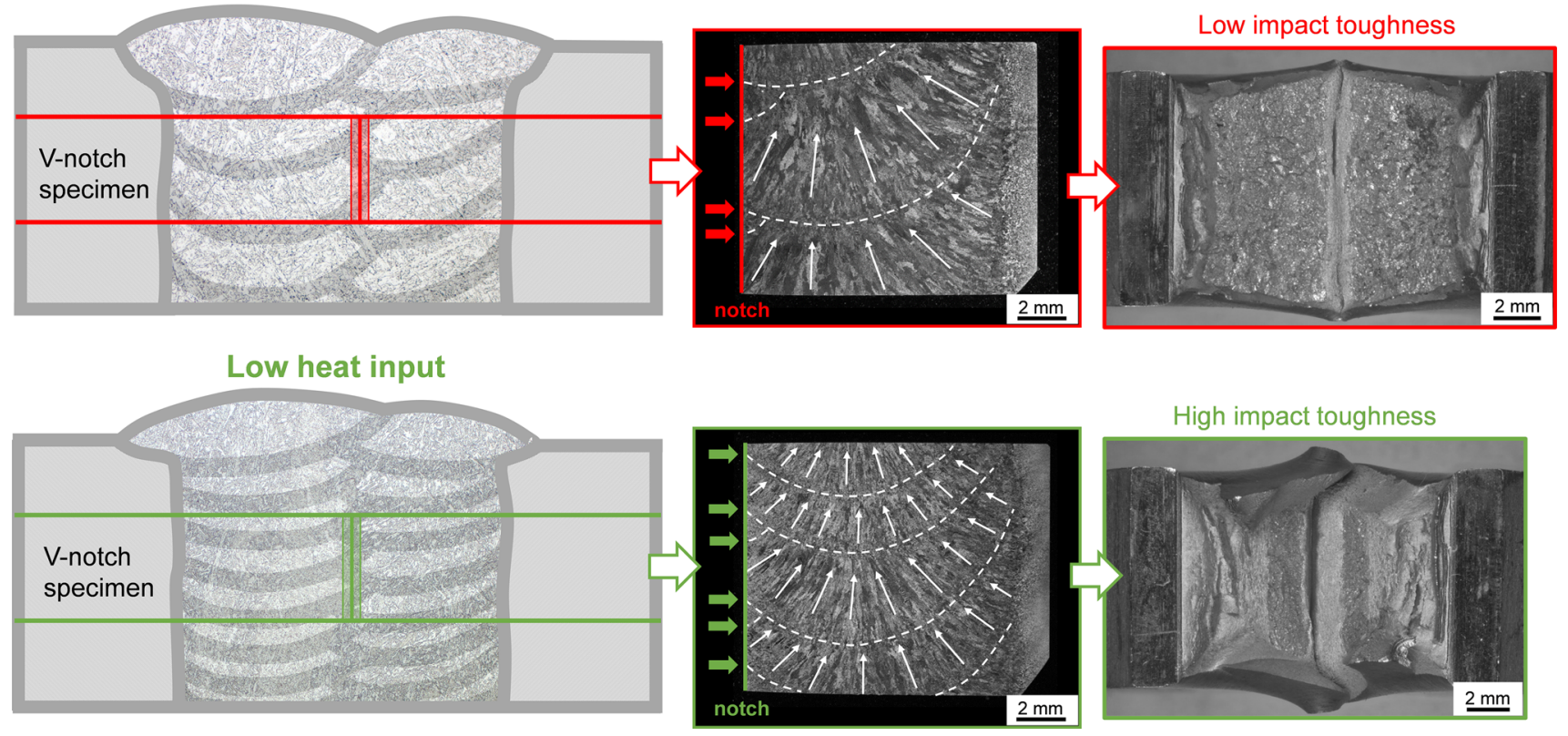

Fig. 18 Schematic drawing of the layer structure of a weld seam produced with high and low heat input. The macro cross sections of the Charpy V-notch specimens and the corresponding fracture surfaces are also shown outlined in green and red, respectively 


\section{Variation of Charpy V-notch position}

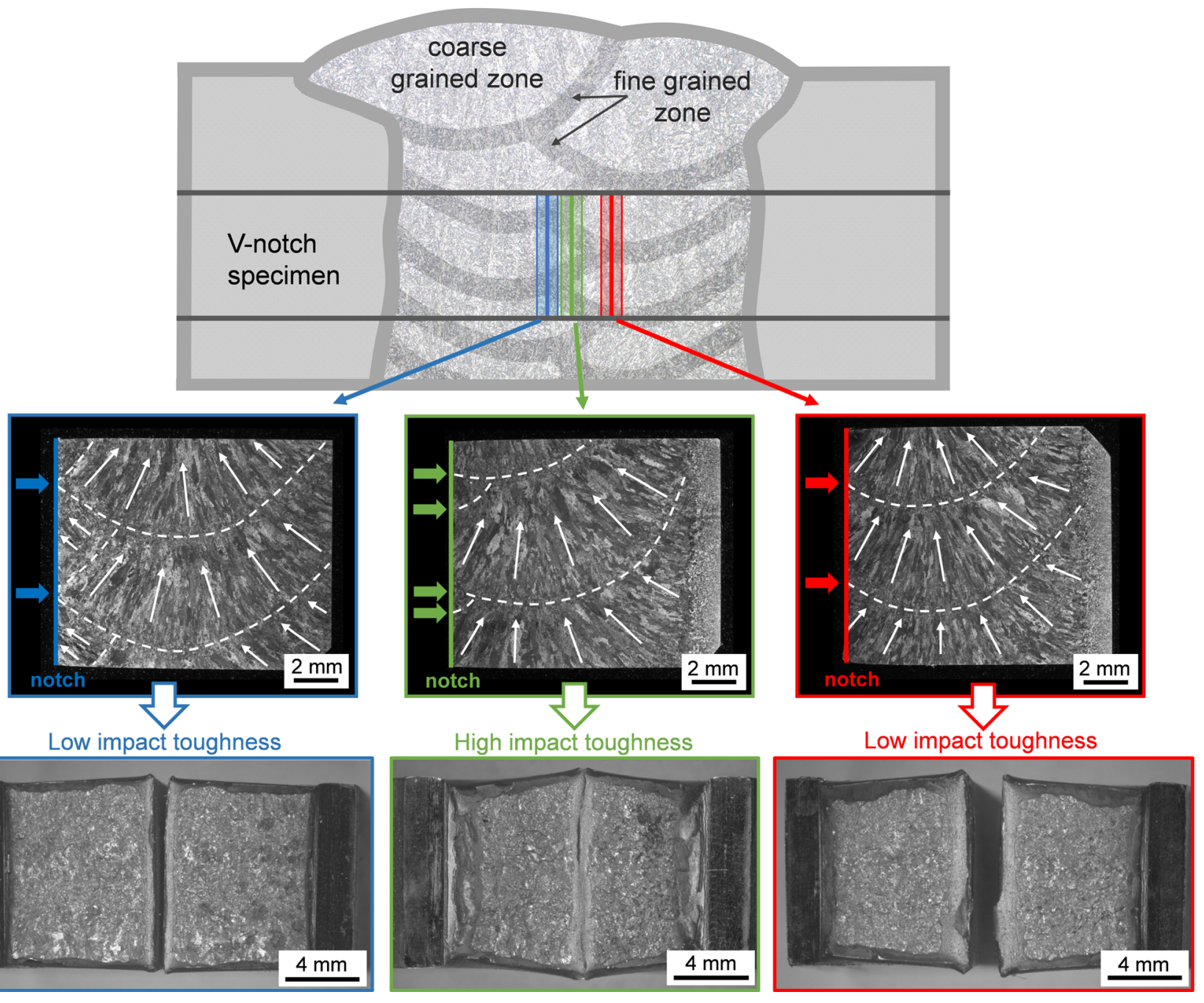

Fig. 19 Schematic drawing of the influence of the V-notch position on the multilayer weld metals cross section on the resulting Charpy impact energy. The macro cross sections of the Charpy V-notch specimens and the corresponding fractured surfaces are also shown (marked in blue, green and red, respectively)

on the impact toughness. Depending on the exact position of the notch on the cross section of the weld seam, and whether it lies in the ideal position (Fig. 19-green notch), higher or lower impact energy values are determined by means of Charpy notch testing. This leads to quite large scattering of the impact energy values as the region where the left and right weld beads cross each other (highest amount of fine grained zone) might slightly shift over the length of the whole weld seam.

The influence of the heat input on the stress rupture time is contrary to its influence on the weld metal's toughness. An increasing heat input during SAW of $2.25 \mathrm{Cr}-1 \mathrm{Mo}-0.25 \mathrm{~V}$ alloy leads to an enhanced stress rupture time which indicates that a higher heat input is beneficial for the weldments creep resistance. Whereby similar to the toughness, the dependence of the stress rupture time on the heat input is strongly pronounced until a heat input of $28 \mathrm{~kJ} \mathrm{~cm}^{-1}$ (weld metal C) is reached and less pronounced for the highest heat input of $32 \mathrm{~kJ} \mathrm{~cm}^{-1}$ (weld metal D). This curve characteristic can also be traced back to the bead sequence of the weld metal specimens as the number of weld layers decreases from weld metal A $\left(20 \mathrm{~kJ} \mathrm{~cm}^{-1}\right)$ to weld metal $\mathrm{C}\left(28 \mathrm{~kJ} \mathrm{~cm}^{-1}\right)$ and stays constant between weld metal $\mathrm{C}$ to weld metal D $\left(32 \mathrm{~kJ} \mathrm{~cm}^{-1}\right)$. This entails an approximately same amount of coarse grained zone which is beneficial for the materials behavior at elevated temperatures and therefore a similar stress rupture behavior was determined for weld metal $\mathrm{C}$ and D. Furthermore, the increase in bainitic grain size with increasing heat input in the last weld bead and the HAZ between the last and the subjacent weld bead leads to the assumption that the creep rupture strength increases with the size of the bainitic structure, which was also demonstrated on the size of martensite variants of differently heat-treated $9 \%$ Cr CrMoV-steels (Ref 43, 44).

Finally, it has to be emphasized that for creep-resistant $2.25 \mathrm{Cr}-1 \mathrm{Mo}-0.25 \mathrm{~V}$ SAW weld metal, stress rupture behavior and toughness have proven to be contrary. Therefore, to obtain an optimal behavior at creep conditions a beneficial compromise between good creep strength and sufficient toughness has to be found by choosing the optimal welding parameters and heat treatment. 


\section{Conclusions}

The present study on the influence of the heat input during SAW on the dendritic solidification structure, the microstructure and the mechanical properties of $2.25 \mathrm{Cr}-1 \mathrm{Mo}-0.25 \mathrm{~V}$ weld metal led to the following conclusions:

- Multilayer SAW with higher heat input leads to broader and thicker weld beads and thus a reduction in weld layers per unit volume.

- Welding with higher heat input entails an increase in the prior austenite and bainitic grain size within the weld beads and the intermediate HAZs of the multilayer weld metal.

- A high heat input during SAW causes an increase in the mean dendrite spacings $\lambda_{\text {prim }}$ and $\lambda_{\mathrm{sec}}$.

- The increased heat input during SAW caused no significant interdendritic segregations of $\mathrm{P}$ and $\mathrm{S}$ in the all-weld metal specimen welded with the highest heat input.

- A higher heat input showed no influence on the strength and ductility of the weld metal at room temperature.

- The heat input has no significant influence on the macrohardness of the resulting weld metal. The macro-hardness is sensitive to the PWHT-time and decreases with longer duration of PWHT at $705{ }^{\circ} \mathrm{C}$.

- A higher heat input leads to a significant decrease in the weld metals impact toughness.

- The stress rupture time, which is an estimation for the weldments creep resistance, is strongly dependent on the heat input during SAW. With increase in heat input, the time to rupture increased.

- The decisive factor which influences the toughness and stress rupture time of the weld metal is its bead sequence. A low heat input during welding leads to fine weld layers and frequent changes between coarse columnar grained weld beads and fine equiaxed grained HAZs between the weld beads leading to a higher amount of fine grained zone within the welded joint which is beneficial for the weld metals toughness and detrimental for its creep resistance.

- For the investigated $2.25 \mathrm{Cr}-1 \mathrm{Mo}-0.25 \mathrm{~V}$ multilayer submerged-arc weld metal, impact toughness and creep resistance behave reversely. An increase in creep resistance entails a reduction of impact toughness.

\section{Acknowledgments}

Funding of the Austrian BMK (846933) in the framework of the program "Production of the future" and the "BMK Professorship for Industry" is gratefully acknowledged.

\section{Funding}

Open access funding provided by Montanuniversität Leoben.

\section{Conflict of interest}

The authors declare that they have no conflict of interest.

\section{Open Access}

This article is licensed under a Creative Commons Attribution 4.0 International License, which permits use, sharing, adaptation, distribution and reproduction in any medium or format, as long as you give appropriate credit to the original author(s) and the source, provide a link to the Creative Commons licence, and indicate if changes were made. The images or other third party material in this article are included in the article's Creative Commons licence, unless indicated otherwise in a credit line to the material. If material is not included in the article's Creative Commons licence and your intended use is not permitted by statutory regulation or exceeds the permitted use, you will need to obtain permission directly from the copyright holder. To view a copy of this licence, visit http://creativecommons.org/licenses/by/4.0/.

\section{References}

1. J. Hucińska, Advanced Vanadium Modified Steels for High Pressure Hydrogen Reactors, Adv. Mater. Sci., 2003, 4(2), p 21-27

2. I. Detemple, F. Hanus and G. Luxenburger, Advanced Steels for Hydrogen Reactors, Hydrocarb. Eng., 1999, 4, p 1-8

3. K. Ichikawa, Y. Horii, A. Sueda and J. Kobayashi, Toughness and Creep Strength of Modified 2.25Cr-1Mo Steel Weld Metal, Weld. J.Incl. Weld. Res. Suppl., 1995, 74(7), p 230-238

4. H. Takauchi, H. Nako and T. Nakanishi, Welding Consumables for 2.25Cr-1Mo-V Refining Reactors, The American Society of Mechanical Engineers, New York, 2017

5. C. Chauvy, S. Pillot, in: ASME Pressure Vessels and Piping Conference, pp. 243-251

6. P.A.S. Pereira, C.S.G. Franco, J.L.M. Guerra Filho and D.S. dos Santos, Hydrogen Effects on the Microstructure of a $2.25 \mathrm{Cr}-1 \mathrm{Mo}-0.25$ V Steel Welded Joint, Int. J. Hydrog. Energy, 2015 https://doi.org/10. 1016/j.ijhydene.2015.07.095

7. H.J. Fahrenwaldt and V. Schuler, Praxiswissen Schweißtechnik, Springer, Dordrecht, 2012

8. U. Dilthey, Schweißtechnische Fertigungsverfahren 1: Schweiß- Und Schneidtechnologien. VDI-Buch, 3rd ed. Springer, Berlin, 2006

9. K.J. Matthes and E. Richter, Schweißtechnik: Schweißen von Metallischen Konstruktionswerkstoffen. Fachbuchverl, Leipzig im Carl-Hanser-Verl, München, 2002

10. G. Hochreiter, Unterpulverschweißen in Der Praxis, Reihe Technik. expert-Verl., Renningen-Malmsheim, 1995

11. P. Müller, L. Wolff, Handbuch des Unterpulverschweißens: Teil I: Verfahren - Einstellpraxis - Geräte - Wirtschaftlichkeit, Teil II: Schweißzusätze und Schweißpulver. Fachbuchreihe Schweißtechnik 63,1/2. Dt. Verl. für Schweißtechnik, Düsseldorf (1983)

12. G. Schulze, Die Metallurgie Des Schweissens: Eisenwerkstoffe Nichteisenmetallische Werkstoffe. VDI-Buch, Springer, Heidelberg, 2010

13. Deutsches Institut für Normung e. V., Schweißen - Empfehlungen zum Schweißen metallischer Werkstoffe: Teil 1: Allgemeine Anleitungen für das Lichtbogenschweißen (EN 1011-1:2009)

14. S. Kou, Welding Metallurgy, Wiley, Hoboken, 2003

15. R.W. Messler, Principles of Welding: Processes, Physics, Chemistry, and Metallurgy. Physiks Textbook, Wiley-VCH, Weinheim, 2004

16. S. Kumar and A.S. Shahi, Effect of Heat Input on the Microstructure and Mechanical Properties of Gas Tungsten Arc Welded AISI 304 Stainless Steel Joints, Mater. Des., 2011 https://doi.org/10.1016/j.matde s.2011.02.017

17. X. Wenkai, Z. Li, Z. Fuju, D. Kesun, Z. Xian, Y. Xue and C. Bingjun, Effect of Heat Input on Cryogenic Toughness of 316LN Austenitic Stainless Steel NG-MAG Welding Joints with Large Thickness, Mater. Des., 2015 https://doi.org/10.1016/j.matdes.2015.07.115

18. K. Prasad and D.K. Dwivedi, Microstructure and Tensile Properties of Submerged Arc Welded 1.25Cr-0.5Mo Steel Joints, Mater. Manuf. Process., 2008 https://doi.org/10.1080/10426910802103551 
19. K. Prasad and D.K. Dwivedi, Some Investigations on Microstructure and Mechanical Properties of Submerged Arc Welded HSLA Steel Joints, Int. J. Adv. Manuf. Technol., 2008 https://doi.org/10.1007/s00 170-006-0855-1

20. B. Kim, S. Uhm, C. Lee, J. Lee and Y. An, Effects of Inclusions and Microstructures on Impact Energy of High Heat-Input Submerged-ArcWeld Metals, J. Pressure Vessel Technol., 2005 https://doi.org/10.1115/ 1.1857933

21. D.M. Viano, N.U. Ahmed and G.O. Schumann, Influence of Heat Input and Travel Speed on Microstructure and Mechanical Properties of Double Tandem Submerged Arc High Strength Low Alloy Steel Weldments, Sci. Technol. Weld. Join., 2000 https://doi.org/10.1179/stw. 2000.5.1.26

22. W. Juan, L. Yajiang and L. Peng, Effect of Weld Heat Input on Toughness and Structure of HAZ of a New Super-High Strength Steel, Bull. Mater. Sci., 2003 https://doi.org/10.1007/BF02707450

23. P. Zhou, B. Wang, L. Wang, Y. Hu and L. Zhou, Effect of Welding Heat Input on Grain Boundary Evolution and Toughness Properties in CGHAZ of X90 Pipeline Steel, Mater. Sci. Eng. A, 2018 https://doi. org/10.1016/j.msea.2018.03.029

24. S. Kumar and S.K. Nath, Effect of Heat Input on Impact Toughness in Transition Temperature Region of Weld CGHAZ of a HY 85 Steel, J. Mater. Process. Technol., 2016 https://doi.org/10.1016/j.jmatprotec.20 16.05.018

25. Welding Calculator voestalpine. https://www.voestalpine.com/alform/ Service/Welding-Calculator. Accessed August 2020

26. Deutsches Institut für Normung e. V., Schweißen - Empfehlungen zum Schweißen metallischer Werkstoffe: Teil 2: Lichtbogenschweißen von ferritischen Stählen (EN 1011-2:2001)

27. API Recommended Practice 934-A, Materials and Fabrication of 2 1/ 4Cr-1Mo, 2 1/4 Cr-1Mo-1/4V, $3 \mathrm{Cr}-1 \mathrm{Mo}$ and 3Cr-1Mo-1/4V Steel Heavy Wall Pressure Vessels for High-Temperature, High-pressure Hydrogen Service, 2nd edn (API Publishing Services, 2008)

28. R. Schnitzer, C. Hofer, S. Mayer, M. Panzenböck, D. Holec and H. Clemens, Multi-Scale Microstructural Characterization-The Role of Classic and High-Resolution Metallography in the Development of Modern High-Performance Materials, Pract. Metallogr., 2018 https://d oi.org/10.3139/147.110531

29. R. Esterl, M. Sonnleitner, M. Stadler, G. Wölger and R. Schnitzer, Microstructural Characterization of Ultra-High Strength Martensitic Steels, Pract. Metallogr., 2018 https://doi.org/10.3139/147.110491

30. A. Brownrigg, P. Curcio and R. Boelen, Etching of Prior Austenite Grain Boundaries in Martensite, Metallography, 1975 https://doi.org/ 10.1016/0026-0800(75)90028-2

31. S. Béchet and L. Beaujard, Nouveau réactif pour la mise en évidence micrographique du grain austénitique des aciers trempés ou trempésrevenus, Rev. Met. Paris, 1955 https://doi.org/10.1051/metal/1955521 00830
32. H. Schönmaier, M. Pölzgutter and R. Schnitzer, Etching Methods for the Microstructural Characterization of a Heat Resistant $2.25 \mathrm{Cr}-1 \mathrm{Mo}-$ 0.25V Weld Metal, Pract. Metallogr., 2020 https://doi.org/10.3139/14 7.110597

33. W. Vanovsek, C. Bernhard, M. Fiedler and G. Posch, Influence of Aluminum Content on the Characterization of Microstructure and Inclusions in High-Strength Steel Welds, Weld. World, $2013 \mathrm{https}: / /$ doi. org/10.1007/s40194-012-0008-0

34. E. Vandersluis and C. Ravindran, Comparison of Measurement Methods for Secondary Dendrite Arm Spacing, Metallogr. Microstruct. Anal., 2017 https://doi.org/10.1007/s13632-016-0331-8

35. Deutsches Institut für Normung e. V., Zerstörende Prüfung von Schweißverbindungen an metallischen Werkstoffen: Längszugversuch an Schweißgut in Schmelzschweißverbindungen (ISO 5178:2019)

36. Deutsches Institut für Normung e. V., Metallische Werkstoffe Kerbschlagbiegeversuch nach Charpy: Teil 1: Prüfverfahren (ISO 148-1:2009)

37. Deutsches Institut für Normung e. V., Zerstörende Prüfung von Schweißverbindungen an metallischen Werkstoffen - Kerbschlagbiegeversuch: Probenlage, Kerbrichtung und Beurteilung (ISO 9016:2012)

38. The American Society of Mechanical Engineers, ASME Boiler and Pressure Vessel Code: Division 2 Alternative Rules, The American Society of Mechanical Engineers, New York, 2017

39. H. Schönmaier, B. Loder, T. Fischer, F. Grimm, R. Krein, M. SchmitzNiederau and R. Schnitzer, Continuous Cooling Transformation Diagrams of 2.25Cr-1Mo-0.25V Submerged-Arc Weld Metal and Base Metal, Metals, 2020 https://doi.org/10.3390/met10081055

40. American Society for Testing and Materials (ASTM), Standard Test Methods for Determining Average Grain Size (E112-10), ASTM International, 2012

41. J.C. Lippold, Welding Metallurgy and Weldability, Wiley, Hoboken, 2014

42. S. Kou, Solidification and Liquation Cracking Issues in Welding, JOM, 2003 https://doi.org/10.1007/s11837-003-0137-4

43. E. Plesiutschnig, C. Beal, S. Paul, G. Zeiler, S. Mitsche and C. Sommitsch, Advanced Microstructures for Increased Creep Rupture Strength of MARBN Steels, MSF, 2014 https://doi.org/10.4028/www. scientific.net/MSF.783-786.1867

44. E. Plesiutschnig, C. Beal, C. Sommitsch, S. Paul and G. Zeiler, Ferritic phase Transformation to Improve Creep Properties of Martensitic High Cr Steels, Scr. Mater., 2016 https://doi.org/10.1016/j.scriptamat.2016. 05.033

Publisher's Note Springer Nature remains neutral with regard to jurisdictional claims in published maps and institutional affiliations. 